\title{
Rongorongo Glyphs Clarify Easter Island Rock Drawings
}

Sergei V. Rjabchikov

\section{(2) OpenEdition \\ 1 Journals}

Electronic version

URL: http://journals.openedition.org/jso/1625

DOI: 10.4000/jso.1625

ISSN: $1760-7256$

Publisher

Société des océanistes

Printed version

Date of publication: 1 December 2001

Number of pages: 215-220

ISSN: 0300-953x

\section{Electronic reference}

Sergei V. Rjabchikov, «Rongorongo Glyphs Clarify Easter Island Rock Drawings », Journal de la Société des Océanistes [Online], 113 | Année 2001-2, Online since 27 May 2008, connection on 30 April 2019. URL : http://journals.openedition.org/jso/1625 ; DOI : 10.4000/jso.1625

\section{(c) Tous droits réservés}




\title{
MISCELLANÉES
}

\section{Rongorongo Glyphs Clarify Easter Island Rock Drawings}

\author{
par Sergei V. RJABCHIKOV *
}

Many Easter Island (Rapa Nui) rock drawings (petroglyphs) can be understood taking into account the readings of the rongorongo records of the famous « talking boards » only. This article is devoted to the study of a new portion of the Rapanui petroglyphs. In deciphering the rongorongo glyphs I use my own classification and translation scheme (Rjabchikov, 1987: 362-363, fig. 1 ; 1993a : 126-127, fig. 1 ; 1993b : 23, fig. 1 ; $1994: 8$, fig. 6 ; 1995a : 5, figs 12 and 17 ; 19972001). Besides, I always take into consideration the vocabularies and rules of alternating sounds of the Polynesian languages.

1. Two fishlike creatures are depicted at Ahu Ra'ai (Lee 1992: 90, figure 4.75). They are a fish and a young one. Glyph $\mathbf{3 0}$ ana is incised on a large fish. This word means 'abundance', $c f$. Hawaiian ana 'to have enough or too much' (Rjabchikov, 2001). Two arcs (cf. Rapanui tapa 'side') represented between the two fish may denote indeed 'offspring' ( $c f$. Rapanui tapa 'offspring').

2. G. Lee (1992: 76, fig. 4.53) believes that large fish shapes depicted at Mahatua are difficult to identify as to species. Really, these are two fish, a Remora (Echeneis) and a tuna-like fish. The first fish identified by a sucker is named paerati, the second is named kahi, pei or remoremo (cf. Randall and Cea Egaña, 1984: 9; Métraux, 1940 : 173). Below the fish combination there is glyph $\mathbf{3 0}$ ana in which glyphs $\mathbf{3 9}$ and 4 are inscribed. I read the word ana 'to have enough or too much' as well as the word rati, i.e. paerati ( $c f$. Rapanui pae 'enough', paepae, paenga 'boat', Maori rato 'to be served; to be distributed').

One can examine glyphs incised on a stone sinker for net or line (Métraux, 1940 : 188, fig. 13b). I have distinguished three glyphs $149 \mathrm{Hatu}$ hatu (epithets of the sun god Makemakel Tangaroa/Tiki/Tane), glyphs 14 Tiki atua 'the deity Tiki' in combination with two glyphs $\mathbf{1 4 9}$ Hatuhatu as well as glyph $\mathbf{4 7}$ ava (cf. Rapanui avaava 'to lift'; on the other hand, this sign may depict a sucker) in combination with two words 39-4 (pae)rati 'the paerati fish'. It is known that according to Rapanui beliefs, the god Makemake was connected with the ocean and fishes (Rjabchikov, 1999a).

3. A fish-in-fish motif is incised at Ava o Kiri (Lee, 1992: 78, fig. 4.58). Another fish-in-fish motif is also incised at the same panel (Van Hoek, 2000: 15, fig. 6). M. Van Hoek (2000 : 16) claims : " To the east, where the sun is 'born', there is the fish-in-fish motif that may be interpreted as a 'pregnant' sea animal representing the beginning of life, although a fish eaten by a larger fish is also a possible interpretation ».

I have investigated both pictures. The first figure (Lee, 1992 : 78, fig. 4.58) includes the fishin-fish (shark-in-shark) motif, glyph $\mathbf{1 0 3}$ under it as well as glyph $\mathbf{4 1}$ and a fish above it. Interestingly, the shark inserted in the larger shark is associated with a crescent. I suppose that the moon design ( $c f$. glyph 3 hina 'the moon', Hina 'the moon goddess') relates to the moon goddess Hina, as in the Hawaiian beliefs the goddess Hina-puku-i'a gives abundance of all the fishes (Beckwith, 1970 : 69). A sentence of the Creation chant can be cited as an example : «Tingahae by copulating with Parararara-hiku-tea produced the shark » (Métraux, 1940: 321). The name Tinga HaelHoe means 'The paddle/ 
hoarseness kills', it is an epithet of the moon goddess Hina (Rjabchikov, 1998-1999). The name Para-rarara-hiku-tea signifies 'The shine/ the heat-the white tail' ${ }^{1}$.

Glyph 103 reads pe that compares with Tahitian pe 'ripe' and Rapanui hakapee no kai hoao 'abundance'. Glyph $\mathbf{4 1}$ ere presented in several Rapanui rock designs and rongorongo records (Rjabchikov, 1995b ; 1999b ; 2000a ; 2001) corresponds to Mangarevan akaere 'to recite genealogies; to show descent', Maori rere 'to be born', reretahi 'one child born at a birth' and Old Rapanui $(h)$ ere 'child; descendant'.

So the script signs of the first motif have allowed to choose the following interpretation: the fish-in-fish denotes the "pregnant» fish only.

The second figure (Van Hoek, 2000 : 15, fig. 6) includes the fish-in-fish motif oriented east-west as well as glyph $\mathbf{3 0}$ ana crossing both fishes. The word ana means either 'abundance' or 'shine; east, the sun' ${ }^{2}$. It is well to bear in mind that the fish is the god Tangaroa's symbol in the Maori mythology (Buck, 1966 : 439).

The tail of a tuna fish is depicted at Pu Hakanini Mako'i (Lee, 1992 : 78, fig. 4.57). Glyph 30 ana is presented near this tail. Again, both interpretations - 'abundance' or 'shine; east, the sun' - are possible.

4. The tail of a tuna fish is depicted at Hanga Oteo (Lee, 1992 : 78, fig. 4.56). Glyph 149 Hatu 'The creator' is incised on this tail. I think that it is a symbol of the sun god (Makemake, Tangaroa, Tane, Tiki te Hatu).

5. A frigate bird, two faces as well as some other petroglyphs are incised at a cave on the islet Motu Nui (Lee, 1992: 73, fig. 4.49). G. Lee (2000 : 112, fig. 6) interprets a part of this rock picture: «This frigate bird is in a cave shelter at Motu Nui. It seems to have a fish near its mouth and a komari below the right wing ». One can try to realise the whole plot. In fact, the vulva form komari (cf. glyph 64 mea 'red') and the fish ( $c f$. glyph $12 i k a$ 'fish') are depicted near the frigate bird ( $c f$. glyph $\mathbf{4 4}$ taha 'frigate bird'). The fish is united with glyph 39 ra'a 'the sun'; a unique petroglyph is presented below the left wing. This sign is a rectangle divided into four parts (one lengthwise rectangle and three cross ones). Since in some instances glyph $\mathbf{4 4}$ taha denotes the name of the tribe union Te Kena of the ruling tribe Miru (Rjabchikov, 1997a : 31), the strange rectangle may be an emblem of the tribe Miru ( $c f$. the lengthwise rectangle) on which territory the tribes Raa 'The sun', Hamea (Ha Mea, i.e. A Mea) 'The red colour' and Marama 'The crescent (or the light)' lived (cf. the three cross rectangles). One can say with a fair degree of confidence that glyphs 64 mea 'red' and 39 ra'a 'the sun' are designations of the tribes Raa and Hamea in this context. The fish depicted near the frigate bird may reflect the fact that the highestranking clan Miru was 'sea' people (Gell, 1993 : 271).

The two masks ( $c f$. glyph $\mathbf{6 0}$ mata 'face; eyes') denote the sun deity Makemakel TangaroalTiki/Tane (Rjabchikov, 1996: 142; 1997b). One of the masks is united with the ribs (cf. Rapanui kavakava 'rib') and with glyph 4 atua 'deity', $c f$. the name of the deity Kava Aro 'The Ribs - the Face/Day/Light' ${ }^{3}$ (Rjabchikov, 1998a : 66). Glyph 149 Hatuhatu 'The creator' is presented near this fragment; $c f$. Rapanui place name Te Mata o Hotu (Barthel 1962: 106) 'The face of the creator'.

The name Kava Aro is written down on the Tahua tablet (Ab 4), see fig. $1: 4321382650$ 115... atualua Kava maa hi taka 'the deity/ dwelling 'The Ribs - the Shine/the Sun' ...' ${ }^{4}$. Interestingly, according to the Easter Islanders, this deity together with the deity Kava Tua lived in the regions of Maunga Parehe or Ra'ai (Englert, 1974: 137 ; Heyerdahl, 1976 : 117). Both place names are associated with a fire and the sun ${ }^{5}$.

6. As has been shown earlier (Rjabchikov, 2000a), signs carved on a hollow stone called the Trumpet of Hiro are connected with the personages of the Rapanui legend "Hiva Kara Rere, the god of the rain ». According to this story, Tare and Tive - the children of the god Tikicould clash the winds. A priest asked the sun deity Tiki to hide his face; the priest also asked the rain deity Hiva Kara Rere to drive the clouds. The parallel plot is presented in the Samoan mythology ( $c f$. Polinsky, 1986 : 314. : the winds

1. $C f$. Rapanui para 'to heat', Maori para 'to shine clearly', Rapanui rararara 'to get warm; to become warm', rara 'side', Maori rara 'rib'

2. $C f$. Rapanui anaana 'shine; to shine; shining'.

3. $C f$. Rapanui aro 'front; forehead; face', Maori ao 'day', aro 'to face, to turn towards', aroaro 'front', Tahitian ao 'day; light', aro 'front; face', Samoan alo 'front', ao 'head; day'.

4. $C f$. Maori ma 'white, clean', whakama 'to make white', hi 'to dawn', hihi 'ray of the sun', Rapanui taka 'round; bright red'.

5. Cf. Rapanui maunga 'mountain', parehaonga 'special earth oven', para 'to heat', Maori para 'to shine clearly', Tahitian he 'crooked'. Rapanui ra'ai signifies 'the sun' (Liller, 1993 : 126). I believe that the place name Parehe is a reflex of the Rapanui legend about the chief (the sun god) Tuki-hakahe-vari-ia-tohu (Rjabchikov, 1997d : 209). 


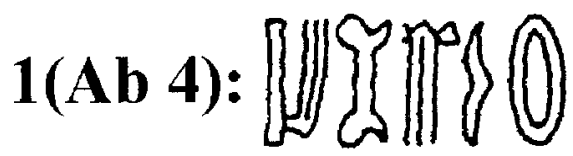

FIG. 1.

$$
\text { 2(I 13): }
$$

FIG. 2.

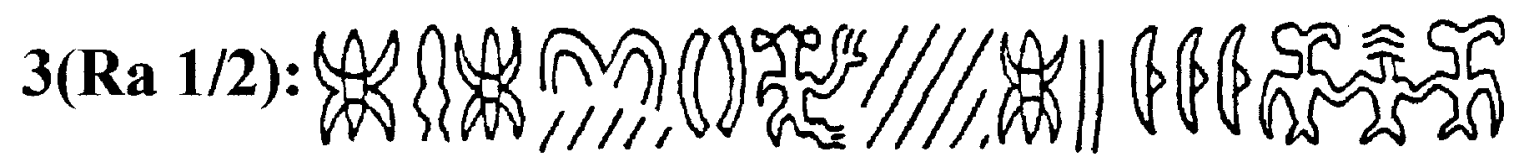

FIG. 3.

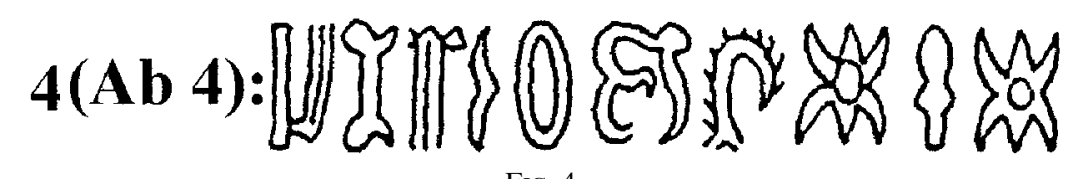

FIG. 1-4. of the final variant of the manuscript « Rongorongo Glyphes Clarity Easter Island Roen Drawings » by Sergei V. Rjabchokov. 
are united by Tiitii [Tiki] or Toiva. The latter name may be split into the words to ( $c f$. Samoan to '(of rain) to fall upon; to come upon') and iva (cf. Maori hiwa 'dark'). So this name means figuratively 'It is raining', and it is comparable with the name Hiva Kara Rere 'The Darkness the wings are flying'. It is well to bear in mind that the sound $h$ can be omitted in the Polynesian words, $c f$., e.g., Rapanui hiva, Marquesan, Mangarevan hiva, iva 'stranger'; Rapanui tuhi 'to alienate', tui 'to expel'; hai, ai 'to wrap up'; hurihuri, uriuri 'black, dark' ; hiri, iri 'to elevate'; Niue uhila, Rapanui uira 'lightning'.

Now one can interpret the names Tare and Tive. The first name correlates with Maori whakatare 'to look intently', and the second name correlates with Maori tiwe 'to scream'. I think that the east ${ }^{6}$ and north-west ${ }^{7}$ winds are the incarnations of Tare and Tive respectively.

In the myth "Ure-a-Oho-Vehi and the two spirits » (Métraux, 1940 : 366 ; Fedorova, 1978 : 284) there are the following words: Ka hau, e ka hau ngaehe. Ka hau te nukunuku Kavakava Aro, Kavakava a Tua... 'May the wind blow, may the wind blow. May the wide extended (deities) Kavakava Aro and Kavakava a Tua ...' 8 . Here the deities Kavakava Aro (Kava Aro) and Kavakava a Tua (Kava Tua) play roles of the deities (winds) Tare and Tive. Actually, the name (Kava)kava Aro signifies 'The Ribs - the Face', this is a mark of the east wind; the name (Kava)kava (a) Tua signifies 'The Ribs - the Back' 9, this is a mark of the north-west wind. The connection of the names Tive (Maori tiwe 'to scream') and (Kava)kava (a) Tua is quite possible because of the wordplay : $c f$. Rapanui kekekeke 'shout' and keke '(of the sun) to set'.

7. A turtle is incised at Hanga Oteo (Lee, 1992 : 48, fig. 4.3). Seven cupules (the seven stars $=$ the Pleiades) and glyph $\mathbf{4 9}$ (ariki) mau are represented inside it. The parallel fragment is presented in an oral version of the rongorongo record «Apai» : tuu hitu (Thomson, $1891:$ :518) 'the seven stars' ${ }^{10}$. Two circles depicted on the border of the turtle sign denote glyph $\mathbf{6 0}$ mata. In compliance with the Tuamotuan and Easter Island beliefs (Lee, 1992: 80; Rjabchikov, 1993c : 5, table $1 ; 1997 \mathrm{a}: 46$ ), the Turtle is a designation of the Pleiades. On the other hand, Hawaiian Makali'i [Matariki] 'the Pleiades' means literally 'Eyes/Face of the Chief' (Beckwith, 1970: 367 ; Rjabchikov, 1998a: 73). Really, glyphs 60-49 mata (ariki) mau correspond to the term Matariki; this name is also registered on the Santiago staff (I 13), see fig. 2 (Rjabchikov, 1993c : 6, table 3). Below the turtle there are six lines which may be the signs of the nights/days or months ( $c f$. Rapanui tika 'landmark', titika 'direct; direct line', Maori totika 'direct', whakatika 'to direct').

8. A comet with a long tail is carved at Vai Atare (Lee, 1992 : 160, fig. 5.33). This plot has been investigated by the author (Rjabchikov, 1997c). One can offer its alternative interpretation: glyph 5 Atua denotes the star Canopus, and glyphs 4125 Rehua denotes the star Antares (Rjabchikov, 2000b; 1999c). There are strong grounds for believing that the comet was indeed Halley's Comet of A.D. 837 or A.D. 1301 (I have used the RedShift 2 computer program).

9. A Vai Atare panel contains many motifs (Lee, 1992 : 161, fig. 5.36). A comet with two tails is Halley's Comet of April 10, A.D. 837 ( $c f$. Belyaev and Churyumov, 1985 : 26). Near this petroglyph there are three moons corresponding to glyphs $\mathbf{3}$ or $\mathbf{6 1}$ hina 'the moon', a frigate bird ( $c f$. glyph 44 taha), a man together with four lines (the wordplay is quite possible : glyph 6 reads $h a$, and Rapanui $h a$ means 'four') and a vulva ( $c f$. glyph 110 vie) including eleven lines. The parallel record is presented on the Small Washington tablet $(\mathrm{Ra} 1 / 2)$, see figure 3: ... 7737124 57-6 ... $7433344443344 \ldots . .$. . Тии Не, tиu « the two tails of Halley's Comet of April 10, A.D. 837 »; Tarahao ... Tuu Atua; hina, hina, hina, taha, taha, ua, taha... 'The star He (Castor? or Pollux? of Gemini; a curved line of stars in Scorpius?), the two tails of Halley's Comet of April 10, A.D. 837; the month Tarahao (March-April) ... the star Canopus; three nights (from the new moon of April 8 till April 10, A.D. 837)' ${ }^{11}$.

The text written down on the Tahua tablet (Ab 4) was partially decoded above. The full name of the deity Kava Aro is as follows (see fig. 4) : 432 1382650115 44-14 7737 atualua Kava maa hi

6. Cf. Rapanui matatohio 'east wind' and Samoan mata'upolu 'ditto' including mata 'eye; face ; look'.

7. Cf. Rapanui papakino 'north-west wind', papakina 'to break; to get broken; to clash', kino 'bad; evil'. It is known that when the north-west wind blows, a sound of the Trumpet of Hiro is akin to that of a trumpet is produced (Métraux, 1940 : 310 ).

8. Cf. Maori $n u k u$ 'to move; to extend; wide extent; distance'.

9. Cf. Rapanui tua 'back; behind', Samoan tua 'back; behind; beyond, outside'

10. $C f$. Old Rapanui tuu 'star'.

11. Cf. the name of the Rapanui statue Tuu He (Mellén Blanco, 1986 : 174). The star He (cf. Tahitian he 'crooked') may correspond to a curved line of stars in the Scorpius constellation, see Best, $1955: 41,57$. Cf. also Rapanui taha 'to go hither and thither', Samoan tafa 'to be visible; to begin to ripen', Rapanui taha 'to tear', tahanga 'one, alone', uaua 'residence', hua 'flower; fruit; to bloom; to sprout'. 
taka; Tahau tuu, He tuu 'the deity/dwelling 'The Ribs - the Shine/the Sun'; \{Castor ? and Pollux ?\} or \{Antares? and the curved line of stars in Scorpius ?\}' ${ }^{12}$. Here the heliacal (morning) rising of these stars is described. The parallel fragment is presented in the folklore text « Apai» : ... Tahau; te Nanai e oho; te Nanai e Rai... (Thomson, 1891 : 518) '... Pollux ? (Castor ?; Antares ?) ; the Spider ${ }^{13}$ is going ; the Spider - the Sun...'.

I suppose that the sign $(\mathrm{Ha})$ depicting a person and the four lines ( $c f$. Rapanui $h a$ 'four') inscribed on the panel denote the star Vega (Rjabchikov, 1999d). Then the three moons and the frigate bird correspond precisely to the rongorongo text; the eleven lines denote in my opinion the eleventh month, Vaitu-nui (April-May); furthermore, the three moons may denote April 8, 9 and 10, A.D. 837.

10. On a red scoria pukao (Van Tilburg and Lee, 1987: 145, fig. 6) at Ahu Akahanga the following petroglyphs are depicted: a twoheaded frigate bird (taha) as well as a frigate bird ( $c f$. glyph $\mathbf{4 4}$ taha) connected with glyphs 3 Hina and $149 \mathrm{Hatu}$. The petroglyph resembling glyph 91 taoraha 'whale' is carved above the latter glyph. As the frigate bird is a symbol of the supreme god Makemake (Métraux, 1940 : 314), the signs of the birds denote his name. As Haua is a local name of the moon goddess Hina (Rjabchikov, $1987: 365$ ), the symbols of the frigate birds and the moon designate the names of the permanent companions, deities Makemeke and Haua (Métraux, 1940 : 313-314). Moreover, the whale is another incarnation of the god Makemake (Rjabchikov, 2000c).

A frigate bird ( $c f$. glyph $\mathbf{4 4}$ taha) is carved together with glyph 3 Hina at the statue quarry of Rano Raraku (Lee, 1992 : 21, fig. 2.4 : the left figure). In my opinion, they are the names of the sun god Makemake and moon goddess Hina.

11. On a red scoria pukao at Ahu Vinapu (Van Tilburg and Lee, 1987: 145, fig. 7) there are petroglyphs some of which are lunate symbols and some others are boat ones. Interestingly, the place name Vinapu signifies 'The producing moon goddess Hina' (Rjabchikov, 1990 : 22). Besides, there are glyphs $\mathbf{1 0 8}$ hiri 'to elevate', (reversed) 3 hina (Kokore), 25 Hua, 4 Atua, 3959 32 Ra'a kau; they correlate with the nights of moon ages (the glyphs read from right to left). Seven cupules may denote the seventh month, Koro (December-January), or the Pleiades, and two big cupules may be the sun signs.

\section{RÉFÉRENCES}

Åkerblom, K., 1968. Astronomy and Navigation in Polynesia and Micronesia: A Survey. Stockholm: The Ethnographical Museum.

BARThel, T.S., 1962. Easter Island Place-Names. Journal de la Société des Océanistes, 18 : 100-107.

Beckwith, M., 1970. Hawaiian Mythology. Honolulu: University of Hawaii Press.

Belyaev, N.A. and K.I. Churyumov, 1985. Kometa Galleya i ee nablyudenie. Moscow: Nauka.

Best, E., 1955. The Astronomical Knowledge of the Maori. Dominion Museum Monograph No 3. Wellington: R.E. Owen, Government Printer.

Buck, P.H. (Te Rangi Hiroa), 1966. The Coming of the Maori. Wellington: Maori Purposes Fund Board, Whitcombe and Tombs Ltd.

Englert, S., 1974. La Tierra de Hotu Matu'a. Historia y etnologia de la Isla de Pascua. Santiago de Chile: Ediciones de la Universidad de Chile.

Fedorova, I.K., 1978. Mify, predaniya i legendy ostrova Paskhi. Moscow : Nauka.
Gell, A., 1993. Wrapping in Images. Tattooing in Polynesia. Oxford: Oxford University Press.

Heyerdahl, T., 1976. The Art of Easter Island. London : George Allen \& Unwin.

LEE, G., 1992. The Rock Art of Easter Island. Symbols of Power, Prayers to the Gods. Los Angeles: The Institute of Archaeology Publications (UCLA).

—, 2000. The Birds of Paradise. Rapa Nui Journal, 14 : 111-114.

LILleR, W., 1993. The Monuments in the Archaeoastronomy of Rapanui. In: S.R. Fischer (ed.) Easter Island Studies. Contributions to the History of Rapanui in Memory of William T. Mulloy. Oxbow Monograph 32. Oxford: Oxbow Books, pp. 122-127.

Mellén Blanco, F., 1986. Manuscritos y documentos españoles para la historia de la isla de Pascua. Madrid : CEHOPU.

MÉtraux, A., 1940. Ethnology of Easter Island. Bernice P. Bishop Museum Bulletin 160. Honolulu: Bernice P. Bishop Museum Press. 
Polinsky, M.S., 1986. Mify, predaniya i skazki Zapadnoy Polinezii (ostrova Samoa, Tonga, Niue i Rotuma). Moscow : Nauka.

Randall, J.E. and A. CEA Egaña, 1984. Native Names of Easter Island Fishes, with Comments on the Origin of the Rapanui People. Occasional Papers of Bernice P. Bishop Museum, Vol. XXV(12). Honolulu: Bernice P. Bishop Museum Press.

RJABChIKov, S.V., 1987. Progress Report on the Decipherment of the Easter Island Writing System. Journal of the Polynesian Society, 96 : 361-367.

-, 1990. Tayny ostrova Paskhi. Vol. 1. Krasnodar: RIO.

_, 1993a. Rapanuyskie texty (k probleme rasshifrovki). Etnograficheskoe obozrenie, 4 : 124-141.

_, 1993b. Notes on the Easter Island Script. L...cho de Rapa Nui, 6(24) : 22-23.

-, 1993c. Tayny ostrova Paskhi. Vol. 2. Krasnodar: Severny Kavkaz.

_ 1994. Notes on the Easter Island Script (part II). L'Écho de Rapa Nui, 7(26) : 7-8.

- 1995a. Notes on the Easter Island Script (part IV). L'Écho de Rapa Nui, 8(32) : 4-5.

_, 1995b. On Inscription in a Basalt Slab. L'Écho de Rapa Nui, 8(30) : 19.

—, 1996. Toponimy ostrova Paskhi, svyazannye s kul'tom ptitsecheloveka. In: V.I. Tkhorik (ed.) Otnositel'nost' abstraktnykh realiy yazyka. Krasnodar: Kuban State University, pp. 141-144.

_, 1997a. Rongorongo versus Kai-kai: A Second Look at Themes Linking Easter Island's Mysterious Script with Its String Figure Repertoire. Bulletin of the International String Figure Association, $4: 30-55$.

—, 1997b. [A Letter to the Editor]. Rapa Nui Journal, $11: 165-166$.

_, 1997c. A Key to the Easter Island (Rapa Nui) Petroglyphs. Journal de la Société des Océanistes, 104(1) : 111.

_, 1997d. A Key to Mysterious Easter Island PlaceNames. Beiträge zur Namenforschung. Neue Folge, 32 : 207-210.

_, 1997-2001. Rongorongo Home Page on the World Wide Web: <http://rongorongo.chat.ru/index. htm $>$.
- 1998a. Polynesian String Figures and Rongorongo: Additional Remarks. Bulletin of the International String Figure Association, 5 : 63-76.

_, 1998b. Rongorongo: The Milky Way and Antares. Rongorongo, Easter Island Writing Home Page: $<$ http://www.openweb.ru/rongo/art4.htm $>$.

—, 1998-1999. Several Rongorongo Records (Symbolism of Archaic Beliefs). AnthroGlobe Journal: $<$ http://anthroglobe.com/bin/artdetail.cgi?ID=11 >

—, 1999a. Tangaroa in the Inscription of the Chicago Fish Tablet. Rapa Nui Journal, 13 : 14-15.

—, 1999b. [A Review:] Fischer, Steven Roger, 1997. Glyphbreaker, New York, Copernicus. Journal de la Société des Océanistes, 108(1) : 168-169.

- 1999c. The Rapanui Names of the Places and Statues. Rongorongo, Easter Island Writing Home Page : $<$ http://www.openweb.ru/rongo/art11.htm>.

—, 1999d. Guy's Reviews Examined. Rongorongo, Easter Island Writing Home Page : <http://www. openweb.ru/rongo/art10.htm>.

—, 2000a. La trompette du dieu Hiro. Journal de la Soc iété des Océanistes, 110(1) : 115-116.

_, 2000b. Astronomical and Calendar Records on Rongorongo Boards. RONGORONGO, Easter Island Writing Home Page : < http://www.openweb. $\mathrm{ru} /$ rongo/art15.htm $>$.

—, 2000c. The Symbolism of the Polynesian Art. Rongorongo Home Page : <http://rongorongo.chat. ru/artrr4.htm>.

-, 2001. On the Inscriptions of the Sydney and Avignon Rei-miro. Rongorongo Home Page: $<$ http://rongorongo.chat.ru/artrr6.htm $>$.

Thomson, W.J., 1891. Te Pito te Henua, or Easter Island. Report of the United States National Museum for the Year Ending June 30, 1889. Annual Reports of the Smithsonian Institution for 1889. Washington : Smithsonian Institution, pp. 447-552.

VAN Hoek, M., 2000. Fish Petroglyphs at 'Ava 'o Kiri, Rapa Nui: An Approximation of a Remarkable Rock Art Site at Easter Island. Rapa Nui Journal, $14: 13-17$.

VAN TilburG, J.A. and G. LeE, 1987. Symbolic Stratigraphy: Rock Art and the Monolothic Statues of Easter Island. World Archaeology, 19(2) : 133-149. 